\title{
Non-obstructive Giant Gastric Trichobezoar: A Case of Rapunzel Syndrome
}

\author{
Obstrüktif Olmayan Dev Gastric Trikobezoar: Bir Rapunzel Sendromu Olgusu
}

\author{
Șener Balas ${ }^{1}$, Oskay Kaya', Nurhan Fıstıkçı ${ }^{2}$ \\ ${ }^{I}$ General Surgery Clinics, Dıskapı Teaching and Research Hospital, Ankara, Turkey; ${ }^{2}$ Psychiatry Clinics, Ardahan State Hospital, \\ Ardahan, Turkey
}

\begin{abstract}
Bezoars are resulted from undigested foods or indigestible foreign materials passed into the gastrointestinal canal. Particularly, mentally ill patients eating foreign materials such as hair, wood or stones have bezoars. In addition, patients with gastric or intestinal bypass surgery may have bezoars. Rapunzel Syndrome is inspired from the tales of Grimm Brothers and constitutes a trichobezoar and a ball of hair hanging down and caus surgery anding obstruction. We presented a giant gastric trichobezoar case without obstruction and weight loss.
\end{abstract}

Key words: bezoars; eating; intestinal obstruction; weight loss

\section{ÖZET}

Bezoarlar sindirilmemiș besinler ya da sindirilemeyen yabancı cisimlerin sindirim kanalında olușturdukları yapılardır. Özellikle mental problemi olan hastalarda saç, tahta parçaları, tașlar vb. cisimler bezoar olușturabilir. Gastrik veya intestinal bypass cerrahi geçirmiș hastalarda da gelișebilirler. Rapunzel Sendromu, Grimm Kardeșlerin masalından esinlenerek trikobezoar ve bundan sarkan saç kuyruğu ve buna bağlı olarak gelișen obstrüksiyon olgularını tanımlar. Bu yazıda, obstrüksiyon ve kilo kaybına yol açmadan büyümüș bir trikobezoar olgusunu sunmayı amaçladık.

Anahtar kelimeler: bezoarlar; yeme; barsak tıkanıkığı; kilo kaybı

\section{Introduction}

Trichotillomania was first described by Hallopeau a French dermatologist in 1889. It occurs as a result of forced and unavoidable impulsive disorder in patients suffering from their own hair pulling ${ }^{1}$. Trichotillomania word comes from the Greek words trichs: hair, tillo: pulling mania: madness. Illness is classified in the

Uzm. Dr. Sener Balas, İrfan Baștŭ̆ Cad. No: 12 Altındă̆, Ankara, Türkive Tel.03125962094Email.senerbalas@yahoo.com

Geliş Tarihi: 11.07.2014 • Kabul Tarihi: 26.07.2014 impulse control disorders ${ }^{1,2}$. Many researchers state that $20 \%$ of patients pulling hairs, also chews and swallows them ${ }^{2}$. Even in one case, the patient was pulling his dog's hairs and eating them ${ }^{1,2}$. In this report we aimed to present a non-obstructive giant trichobezoar without weight loss.

\section{Case Report}

A 17 year-old female patient was admitted to surgical outpatient clinic for abdominal pain and stress. The patient's body mass index (BMI) was 28 and her nutritional status was normal.

Physical examination revealed a good general condition with normal vital signs. During the abdominal examination we observed a painless mass in the left upper quadrant. The rest of the physical examination was unremarkable.

Biochemical tests and complete blood count were normal. Ultrasound and computed tomography examinations revealed a space occupying lesion that could possibly be trichobezoar (Figure 1). Thus we performed an upper gastrointestinal endoscopic exploration and found out a trichobezoar filling the stomach and extending into the duodenum.

We could not fragment the bezaor and thus, had to perform surgical exploration. The patient was operated by a midline incision. During the surgical process we observed that the stomach was elongated and pithotic (Figure 2). We also palpated the gastric bezoar and demonstrated that it was extending in to the duodenum. The bezoar was pulled out from the gastrotomy incision made on the anterior wall of stomach. Gastrotomy was closed by two layers running absorbable suture (Figures 3, 4). 


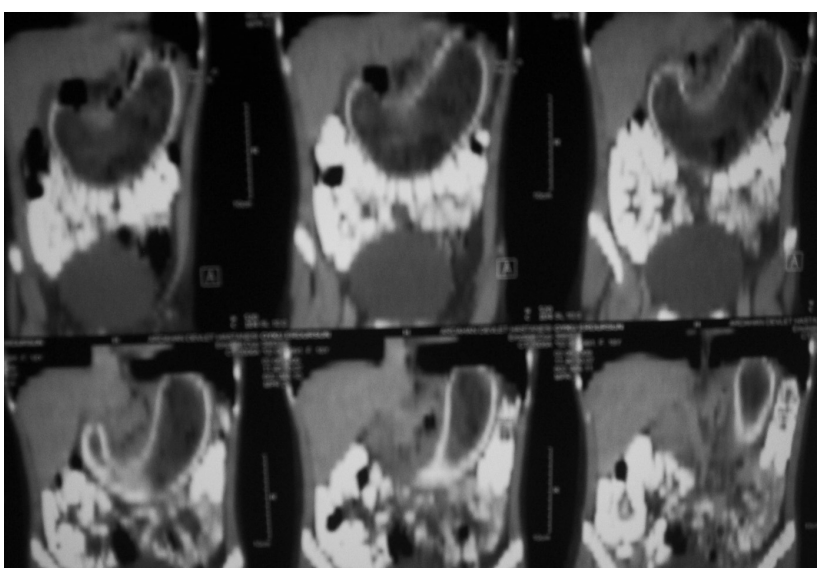

Figure 1. Tomographic view of the bezoar.

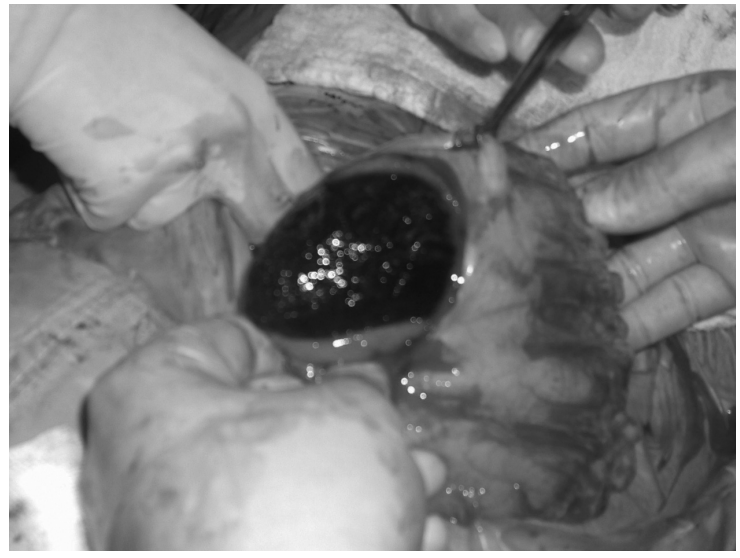

Figure 3. Removal of the bezoar out of the stomach.

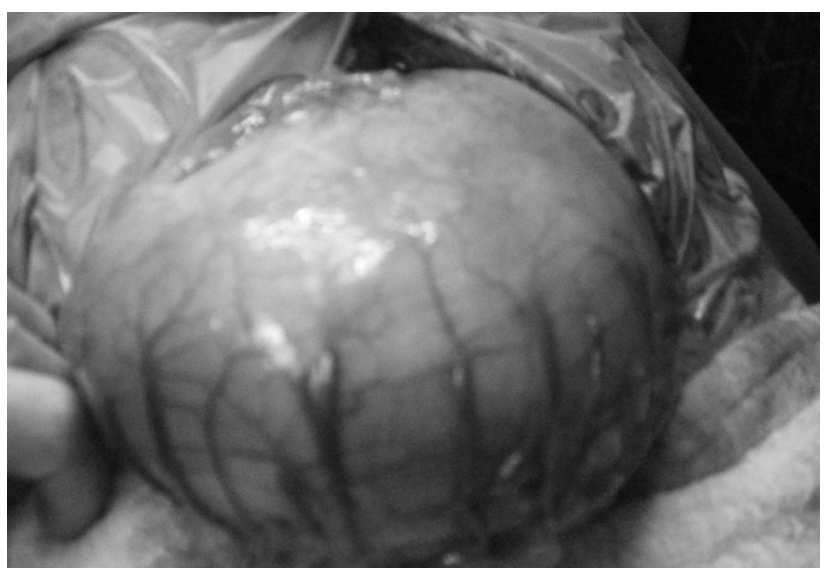

Figure 2. The image of the stomach during the operation.

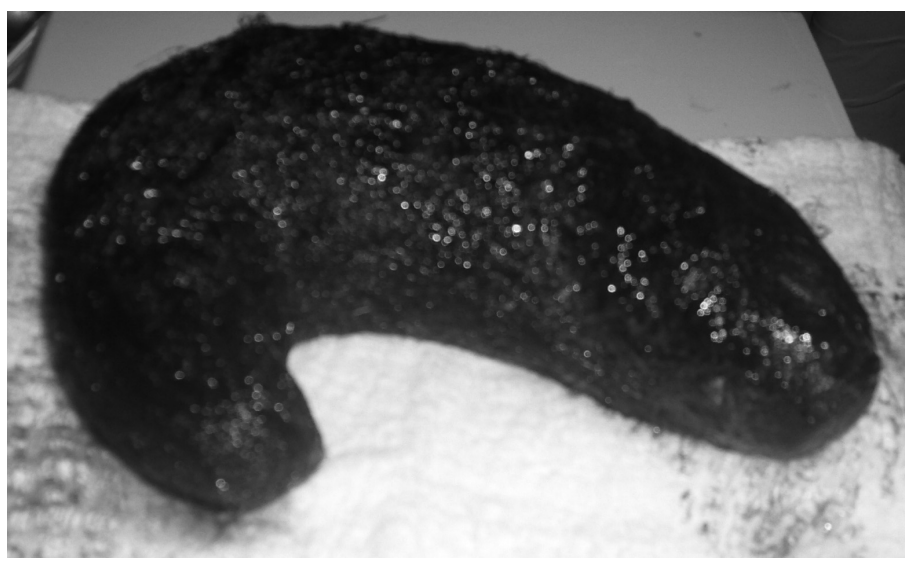

Figure 4. Gross appearance of the bezoar.
Postoperative period was uneventful and the patient began to ingest oral clear liquids on the third day. She was discharged on the fifth day. On the first month follow up visit, she was well and symptom free.

\section{Discussion}

Trichophagia begins with putting the hairs between the teeth and following chewing and swallowing many hairs get down into the stomach. This condition of the gastrointestinal lumen is called trichobezoar ${ }^{1,2}$.

Our patient was eating her hair during stressed conditions. We could not provide information about the time of the initiation of the symptoms. Generally, these patients have alopecic areas on their scalp, however we could not find those kind of areas on the scalp of our patient. Bezoars are frequent in second decade especially among adolescent girl patients. To our knowledge, the medical literature does not include an adult patient with Rapunzel Syndrome ${ }^{2}$.
Most common complaints of patients are abdominal pain and weight loss. Fullness in the abdomen, nausea and vomiting are common symptoms ${ }^{2,3}$. In our case main complaint was abdominal pain, however, it was remarkable that she has no complaints about eating problems or intestinal passage. Bezoars can lead gastric and intestinal ulcers, bleeding or perforations ${ }^{4}$. If sufficient enlargement occurs, bezoars can lead pancreatitis, colonic obstructions or chronic anemia due to gastric ulcers ${ }^{2,4,5}$.

The diagnosis of a bezoar is frequent and easy in adult patients who have previous gastric surgery; however diagnostic clues are usually lacking during childhood. Gastric bezoars must be considered as one of the probable diagnosis in a child or an adolescent patient who has a palpable mass in the left upper quadrant ${ }^{5}$.

Although, it is not a specific finding, a mild anemia and leucocytosis may accompany the condition ${ }^{5}$. In the cases with obstructive symptoms, there may be fluid and 
air levels in plain films ${ }^{6}$. Intraluminal highly echogenic air line and its posterior acoustic shadow are monitored in ultrasonography and this view distinguishes it from the gas or food scraps ${ }^{6}$. Abdominal computed tomography may help to rule out the calcified tumors ${ }^{6}$. We used both imaging modalities and determined the bezoar with ultrasound and then confirmed the diagnosis with tomography.

Endoscopy is an efficient diagnostic technique for bezoars located in the upper gastrointestinal channel, and pulling them out may be therapeutic. Only 25\% of the bezoars determined endoscopically can be seen through barium films ${ }^{7}$. In our case, a bezoar almost completely filling the stomach and extending into the duodenum was detected through gastroscopy. Since the bezoar was too big to be broken down endoscopically, surgery was planned.

Although there are some medical treatment choices for phytobezoars, trichobezoars fail to benefit from medical treatments ${ }^{8}$. With the technological developments, extracorporeal lithotripsy, endoscopic breaking down, crashing by laser or laparoscopic pulling down have become possible. However, surgery is still accepted as the most efficient method for complicated large tricobezoars?

Breakings down of the bezoars via laparoscopically inserted gastric port were described. Although the method has longer procedure time, it has smaller incisions and lower peritoneal contamination risks?.

Rapunzel Syndromes are rare and can be found as case presentations in the medical literature. Regarding their 3 cases' presentation along with 23 previous ones, Nalk et $\mathrm{al}^{10}$ reported that all the patients were surgically treated. Uncontrollable behavioral disorders secondary to certain psychiatric disorders may be associated with the recurrence of the disease. In order to prevent recurrences, appropriate and efficient psychiatric treatment and follow ups are necassary.

\section{References}

1. Millard LG. Trichotillomania In: Lebwohl MG, Heymann WR, Berth-Jones J, Coulson I, editors. Treatment of Skin Disease: Comprehensive Therapeutic Strategies, Fourth Edition Elsevier; 2014. p.239, 773-4.

2. Ceylan ME, Çetin M. Araştırma ve Klinik Uygulamada Biyolojik Psikiyatri 3. baskı; Küre İletişim Grubu, İstanbul, 2005:1117-32.

3. Salena BJ, Hunt RH. Bezoars. In: Sleisinger MH, Fordtran JS, editors. Gastrointestinal disease. Vol 1 5th ed. Philadelphia: Saunders; 1993:758.

4. Perez E, Santana JR, Garcia G. Gastric perforation due to trichobezoar in an adult. Cir Esp 2005;78:268-70.

5. İslek A, Sayar E, Yilmaz A. A rare outcome of iron deficiency and pica: Rapunzel syndrome in a 5-year-old child iron deficiency and pica. Turk J Gastroenterol 2014;25:100-2.

6. Mathai J, Chacko J, Kumar T, et al. Rapunzel syndrome: a diagnosis overlooked. Acta Pediatrica 2007;96:135-8.

7. Wijetilleke A, Sarkan M, Kamat-Nerikar R. Vomiting in a girl with autism. Clin Pediatr 2009;48:224-7.

8. Ladas SD, Triantafyllou K, Tzathas C, et al. Gastric phytobezoar may be treated by nasogastric Coca-Cola lavage. Eur J Gastroenterol Hepatol 2002;14:801-3.

9. Dorn HF, Gillick JL, Stringel G. Laparoscopic intragastric removal of giant trichobezoar. JSLS 2010;14:259-62.

10. Naik S, Gupta V, Naik S, et al. Rapunzel syndrome reviewed and redefined. Dig Surg 2007;24:157-61. 